\title{
DETERMINATION OF VEGETATION AND SOIL PROPERTIES OF THE FLOODPLAIN RANGELAND IN THE CONTINENTAL CLIMATE ZONE OF TURKEY
}

\author{
DEMIRHAN, E. - ÖZYAZICI, M. A.* \\ Department of Field Crops, Faculty of Agriculture, Siirt University, Siirt, Turkey \\ *Corresponding author \\ e-mail: arifozyazici@siirt.edu.tr; phone: +90-532-633-4592 \\ (Received $2^{\text {nd }}$ Aug 2019; accepted $14^{\text {th }}$ Nov 2019)
}

\begin{abstract}
This study was conducted in May 2017 to investigate vegetation and soil properties of a floodplain rangeland, which is located in the continental climate zone of Turkey. In the study, vegetation surveys were performed in the rangeland areas with two different slope degrees (0-1\% and 2-5\%), and the Modified Wheel Point method with loop was used in vegetation measurements. A total of 23 different species belonging to 20 genera from 9 families, were identified in the rangeland where vegetation surveys were conducted. It was determined that 2 of the identified species were decreaser, 2 of them were increaser, and 19 of them were invasive species. The plant cover ratio of the studied rangeland area where the study was conducted covered with the plant was $76.87 \%$. In general, the ratio of the Poaceae in the botanical composition of the examined rangeland was $35.32 \%$, the ratio of legumes was $28.60 \%$, and the ratio of other families was $36.08 \%$. The examined rangeland soils had medium structure, mild alkaline character, and no salinity problem. It was determined that organic matter, available phosphorus and potassium content of the rangeland's moderately calcareous soils were higher in the base areas than in the slightly inclined areas.
\end{abstract}

Keywords: rangeland, botanical composition, plant cover percentage, Fabaceae, soil properties

\section{Introduction}

Meadows and rangelands covering approximately $25 \%$ of the Earth's land area (Alkemade et al., 2013), in addition to providing important ecosystem products and services to many people (Sala et al., 2017), being the most important source of roughage for livestock (Seydoşoğlu et al., 2019) and hosting wildlife, are also known as important areas in terms of having rich biodiversity and storing about 10-30\% of the world's terrestrial carbon (Derner et al., 2006; Booker et al., 2013). While in Turkey these areas covered about 44 million hectares in the 1940s, nowadays they have been decreased to 14.6 million ha, and they constitute $38 \%$ of the total agricultural area (Anonymous, 2019a). In Turkey, available meadow and rangeland areas can meet about $20 \%$ of the roughage need of existing animals $(\sim 16$ million animal unit) (Çaçan and Yüksel, 2016; Demiroğlu Topçu and Özkan, 2017). Meadows and rangelands, which provide the cheapest input for animal production, seem to be far from meeting the need for feed, and the reason for this is undoubtedly them having low feed production and/or yield. The free grazing system is effective on low amount of feed obtained from rangelands around the World as well as in Turkey. However, the full implementation of sustainable rangeland management can be achieved by following the principles of correct use and management.

According to the results of many studies conducted on rangelands in Turkey, it is reported that dry herbage yield of rangelands range between $640-2920 \mathrm{~kg} \mathrm{ha}^{-1}$ according to the differences in ecology, vegetation and application and they have lost their yield 
ability (Terzioğlu and Yalvaç, 2004; Polat et al., 2018; Sürmen and Kara, 2018), that in many rangeland vegetations, the ratios of plant species with high feed yield and quality were found to be low, while the ratios of invasive species were found to be high (Gür and Altın, 2015; İspirli et al., 2016; Seydoşoğlu et al., 2019; Seydoşoğlu and Kökten, 2018, 2019; Tutar and Kökten, 2019), in other words, that rangelands are away from climax vegetation and produce feed below their potential (Aydin and Uzun, 2005, 2008), and that there is an urgent improvement need in Turkey's rangelands (Yavuz et al., 2011, 2012; Alay et al., 2016).

In order to achieve success in rangeland improvement, which aims to create better vegetation and bring the rangeland to a position so that it can produce high-quality feed with high yield, knowing the vegetation structure of the rangeland to be improved. (Çınar et al., 2019) and listing the species from which the vegetation is composed, i.e. the plant species composing it, are important. Determination of the botanical composition, which is the main character of plant communities, constitutes the first and primary step of investigating meadow and rangeland vegetations (Gençkan, 1985).

Together with the biotic factors constituting the living environment, abiotic factors such as climate, soil, and topography are effective in the formation, development, and extinction of meadow and rangeland vegetations. For this reason, it is extremely important to know and/or reveal some physical and chemical properties of rangeland soils, especially in order to shed light on rangeland improvement studies. On the other hand, slope differences in rangeland areas affect soil fertility, the ratio of plant-covered areas, and ultimately, the meadow and rangeland crop significantly (Sürmen and Kara, 2018). This study aimed to determine vegetation and soil properties of a floodplain rangeland, which is located in the continental climate zone of Turkey.

\section{Materials and methods}

\section{General description and some geographical features of the study area}

The study was conducted in 2017 in the floodplain rangeland of Gözpınar village in Kurtalan district of Siirt province, which is located in the Southeastern Anatolia Region of Turkey (Fig. 1). Kurtalan district is located between $37^{\circ} 55^{\prime} 36^{\prime \prime}$ north latitude and $41^{\circ} 42$ ' 9" east longitudes, and Gözpınar village, where the study was conducted, is located between $37^{\circ} 58^{\prime} 35.0328^{\prime \prime}$ north latitude and $41^{\circ} 27^{\prime} 24.5304^{\prime \prime}$ east longitudes (Anonymous, 2019b).

Siirt province is located within the borders of the Dicle Region of Turkey's Southeastern Anatolia Region, and it is surrounded by Şırnak and Van provinces to the east, Batman and Bitlis provinces to the north, Batman province to the West, and Şırnak and Mardin provinces to the south. Siirt province consists of mountains and hills topographically, and the western part of the province including Kurtalan district is composed of plains that are mainly flat and close to flat. Some flatlands extend from Kurtalan district center to Batman province border and are severed from each other. The average elevation of the plain, which displays a rough structure and spreads over an area that is not very wide, is between 550-850 m (Anonymous, 1997). Areas with low slope values, lands entering in the "no or little erosion" class, and deep and medium-deep soils are also located in the western part of the province. The dominant large soil group in the study area is brown soils (Özyazıcı et al., 2014). The examined rangeland has a homogeneous area in terms of the drought index, aspect, and altitude (Avağ et al., 2012). 


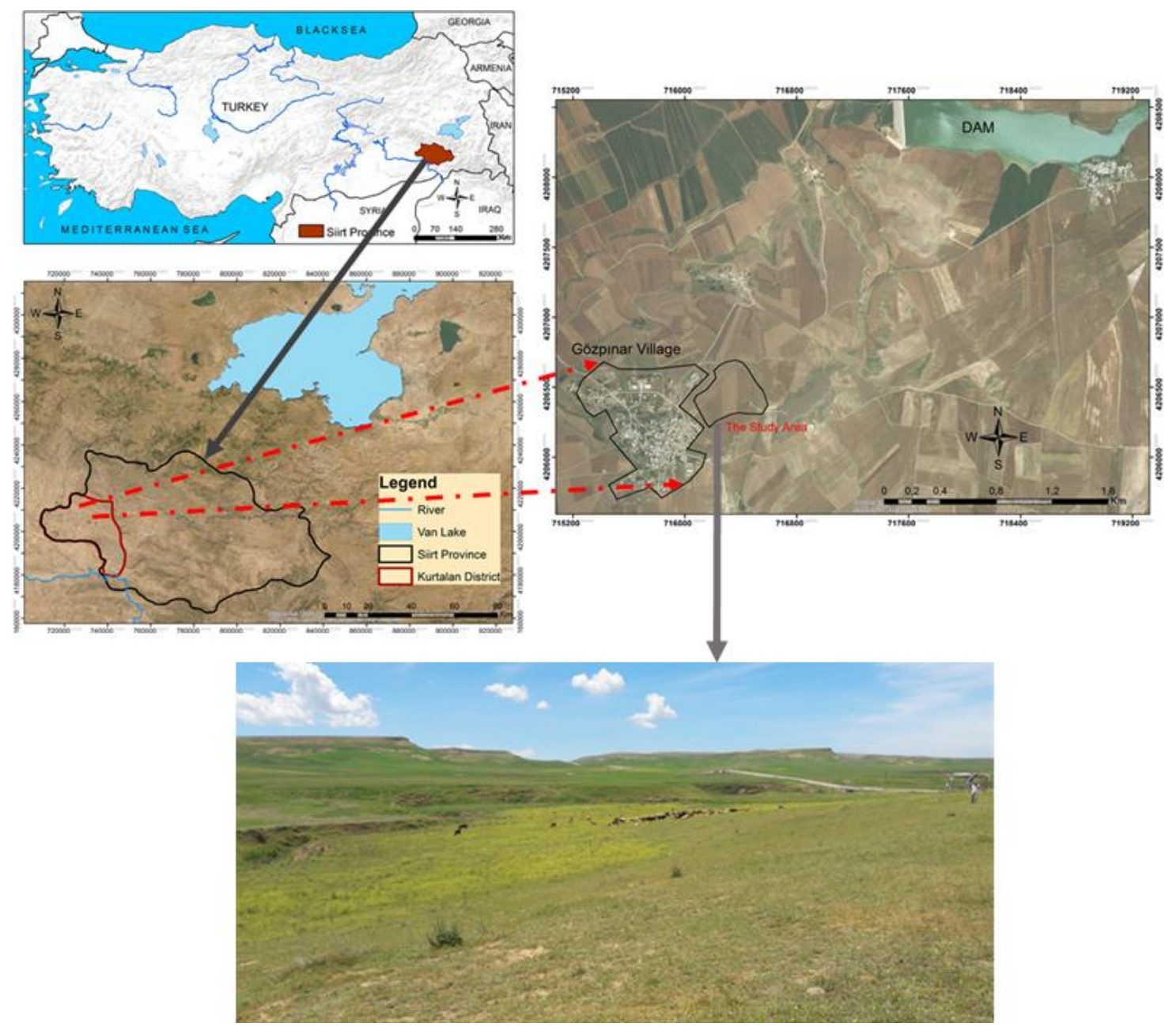

Figure 1. Location of the study area

A continental climate generally dominates Siirt province. Summers are hot and dry. Not much rainfall is observed between June and October. According to the long-term climatic data (1980-2017), the average annual temperature of the study area was $16.4^{\circ} \mathrm{C}$, and the average of annual rainfall was $700.3 \mathrm{~mm}$. The average annual temperature in 2017 , when the study was conducted, was recorded to be $17.2{ }^{\circ} \mathrm{C}$ and the total annual rainfall amount was recorded to be $547.9 \mathrm{~mm}$ (Fig. 2).

\section{Vegetation measurement methods}

In the study, vegetation surveys were performed in May 2017 in the Gözpınar village rangeland, in the regions with two different slope degrees (0-1\% and 2-5\%). The Modified Wheel Point method with loop was used in vegetation measurements (Koç and Çakal, 2004). The measurements were carried out in the Gözpınar village rangeland, in the part with two different slope degrees, during the flowering period of dominant plants in the rangeland, in 3 different part (in the block) which were very homogeneous in terms of vegetation and soil, and along four 20-m long lines, which extended from a point considered as the center towards 4 main directions (east, west, north, and south) in each part (in the block). Plant reading was performed to be 100 in total on each 20-m line and 400 in each block (Gökkuş et al., 2000). 


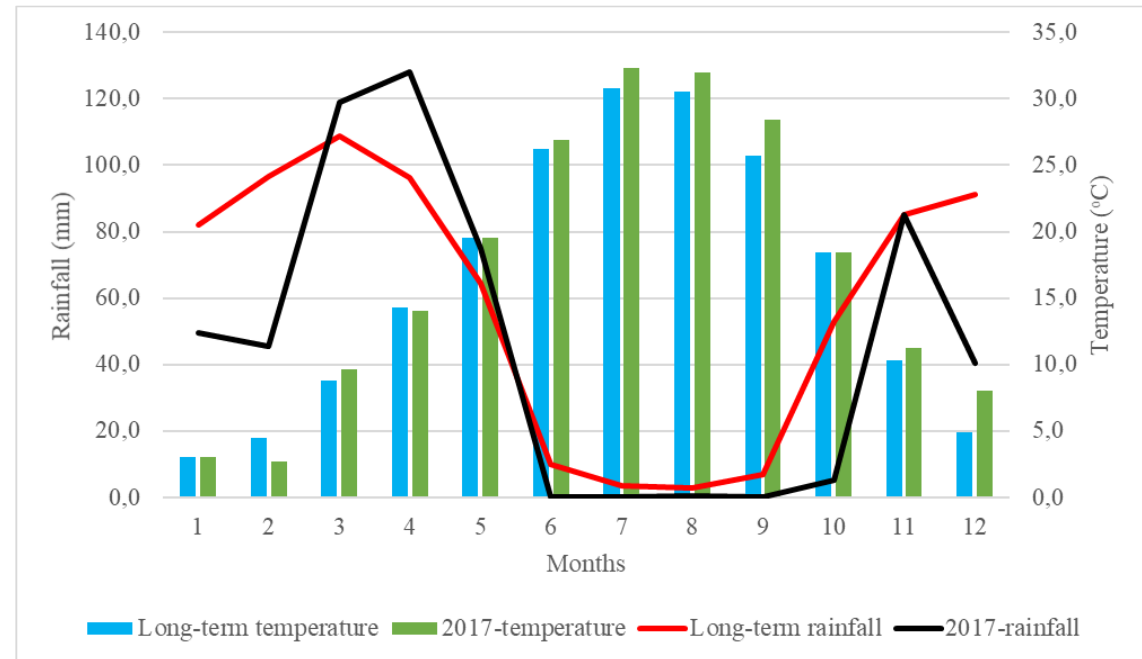

Figure 2. Long-term (1980-2017) and 2017 climate diagram for Siirt province

Identification of plants found in vegetation surveys was performed by benefiting from the studies carried out by Edgecombe (1964), Garms et al. (1968), Davis (1969), Polunin and Huxley (1974), Huxley and Taylor (1977), Weymer (1981), Demiri (1983), and Öztan and Okatan (1985).

The lifespan and families of the species and the degree of effect which expresses the plant species' palatability and response to grazing (decreaser, increaser, and invasive species) were determined according to Anonymous (2008).

In the rangeland, the plant coverage ratio (PCR) was determined by proportioning the number of points, where a plant was observed during the vegetation survey, to the total number of measured points, and it was expressed as a percentage (\%) according to Gökkuş et al. (2000). By proportioning the values of each plant species to the total number of plants, the botanical composition ratio (BCR) was determined (Gökkuş et al., 2000). The BCR were calculated by separating the plant species observed in each loop line in the studied rangeland into three different plant groups, such as the Poaceae, Fabaceae, and other families.

\section{Soil analysis methods}

In the rangeland area, in each block where vegetation measurement was made, soil samples were taken from $0-20 \mathrm{~cm}$ soil depth with a stainless steel shovel following the general rules (Jackson, 1958). Soil samples were laid on clean packaging paper under laboratory conditions, stone and plant particles were picked over, and they were allowed to air dry. All dried soils were ground with wooden mallets, passed through a $2 \mathrm{~mm}$ steel sieve, and made ready for analysis.

The particle size distribution of soil was performed with the Bouyoucus hydrometer method; soil reaction $(\mathrm{pH})$ was determined in the prepared saturated soil paste using a $\mathrm{pH}$ meter with a glass electrode; total salt was determined with the extract obtained from saturated soil paste using a conductivity device; lime was determined using a Scheibler calcimeter; organic matter was determined by the modified Walkley Black method; the available phosphorus was determined according to the Olsen method; the available potassium was determined with the extraction method by using $1 \mathrm{~N}$ ammonium acetate $(\mathrm{pH}=7.0)$ (Anonymous, 1982, 1986). 


\section{Results and discussion}

\section{Vegetation characteristics}

The species detected at different slope degrees in the Gözpınar village rangeland during the study and vegetation characteristics of these species were presented in Table 1. As it can be observed from Table 1, in the rangeland of Gözpınar village, 23 species belonging to 20 different plant genera from 9 different families were detected in the region which has $0-1 \%$ slope degree, 21 species belonging to 19 different plant genera from 8 different families were detected in the region which has $2-5 \%$ slope degree, and in general, a total of 23 different species belonging to 20 genera from 9 families were detected in the Gözpınar village rangeland.

In similar studies conducted in natural rangelands of Turkey, the number of species was reported to be 207 in the rangelands of Samsun by Yavuz et al. (2011), 186 in Amasya rangelands by Yavuz et al. (2012), 53 in a rangeland in Derik district of Mardin province by Aydin et al. (2014), 41 in the floodplain rangelands of Kirikhan district of Hatay province by Çınar et al. (2014), 122 in the Zengi rangeland of Isparta province by Babalık and Sarıkaya (2015), 206 in the rangelands of Karahisar village of Tekirda $\breve{g}$ province by Gür and Altın (2015), 90 in Çanakkale rangelands by Özaslan Parlak et al. (2015), 43 in the floodplain rangelands of Silvan district of Diyarbakir province by Seydoşoğlu et al. (2015a), 35 in the steppe rangelands of Eğil district of Diyarbakır province by Seydoşoğlu et al. (2015b), 103 in the rangelands of Taşköprü district of Kastamonu province by İspirli et al. (2016), 176 in the rangelands of Antalya province by Öten et al. (2016), 89 in the Karaören village rangeland within the boundaries of Seyitgazi district of Eskişehir province by Babalık and Ercan (2018), 117 in the rangelands of Beşiri district of Batman province by Seydoşoğlu and Kökten (2018), 202 in Batman province rangelands by Seydoşoğlu and Kökten (2019), and 53 in the Ormanardı village rangeland of Bingöl city center by Tutar and Kökten (2019). The difference in terms of the number of species between the data reported in the literature and the results of our study could be explained by the differences in grazing pressure, climate, soil structure, and topographic structure between the rangelands.

The family with the highest number of species in the examined rangeland area is the Poaceae, and this family was followed by the Fabaceae, and by the Brassicaceae, Asteraceae, and Umbelliferae families with two plant species in each of them (Table 1).

The lifespan that expresses a meaning within the "Life Form," which constitutes one of the qualitative characteristics of meadow and rangeland vegetation, is important in terms of plant sociology and ecology, and it is an important feature that needs to be emphasized in the subject of culture, management, and rehabilitation of meadows and rangelands (Gençkan, 1985). In this study, according to the life spans, in the rangeland section with a slope degree of $0-1 \%, 15$ of the plant species were detected to be annual and 8 of them to be perennial; in the region section with a slope degree of $2-5 \%, 13$ of the plant species were detected to be annual and 8 of them to be perennial (Table 1). In vegetation studies carried out in similar ecologies, for example, in the studies carried out in the rangelands of Derik district of Mardin province (Aydın et al., 2014), in the floodplain rangelands of Silvan district of Diyarbakır province (Seydoşoğlu et al., 2015a) and in steppe rangelands of Eğil district of Diyarbakır province (Seydoşoğlu et al., 2015b), as in the results of our study, annual species were reported to be present more in vegetation. The fact that annual species constitute the majority means that the rangeland loses its natural vegetation characteristics. 
Table 1. The species detected at two different slope degrees of the Gözpinar village rangeland, families of the species, their lifespans, responses to grazing (effect), plant coverage ratio $(P C R)$, and botanical composition ratio $(B C R)$

\begin{tabular}{|c|c|c|c|c|c|}
\hline Species & Family & Lifespan & Effect & PCR (\%) & BCR (\%) \\
\hline \multicolumn{6}{|c|}{$0-1 \%$} \\
\hline Avena sterilis & Poaceae & Annual & Invasive & 5.00 & 6.03 \\
\hline Bromus tectorum & Poaceae & Annual & Invasive & 1.00 & 1.20 \\
\hline Dactylis glomerata & Poaceae & Perennial & Decreaser & 1.00 & 1.20 \\
\hline Hordeum murinum & Poaceae & Annual & Invasive & 11.75 & 14.15 \\
\hline Hordeum spontaneum & Poaceae & Annual & Invasive & 5.50 & 6.63 \\
\hline Lolium perenne & Poaceae & Perennial & Decreaser & 2.75 & 3.31 \\
\hline Poa bulbosa & Poaceae & Perennial & Increaser & 2.00 & 2.42 \\
\hline Astragalus hamosus & Fabaceae & Annual & Invasive & 7.00 & 8.44 \\
\hline Medicago rigidula & Fabaceae & Annual & Invasive & 4.75 & 5.72 \\
\hline Trifolium campestre & Fabaceae & Annual & Invasive & 5.00 & 6.03 \\
\hline Trifolium subterraneum & Fabaceae & Annual & Invasive & 3.75 & 4.52 \\
\hline Trigonella monantha & Fabaceae & Annual & Invasive & 2.50 & 3.01 \\
\hline Trigonella monspeliaca & Fabaceae & Annual & Invasive & 1.00 & 1.20 \\
\hline Aristolochia bodamae & Aristolochiaceae & Perennial & Invasive & 2.50 & 3.01 \\
\hline Capsella bursa-pastoris & Brassicaceae & Annual & Invasive & 1.50 & 1.81 \\
\hline Cardaria draba & Brassicaceae & Perennial & Invasive & 1.25 & 1.51 \\
\hline Chardinia orientalis & Asteraceae & Annual & Invasive & 3.00 & 3.60 \\
\hline Taraxacum aleppicum & Asteraceae & Perennial & Invasive & 5.50 & 6.63 \\
\hline Parentucellia latifolia & Scrophulariaceae & Annual & Invasive & 2.00 & 2.42 \\
\hline Scandix stellata & Umbelliferae & Annual & Invasive & 6.25 & 7.52 \\
\hline Torilis leptophylla & Umbelliferae & Perennial & Invasive & 5.00 & 6.03 \\
\hline Teucrium polium & Lamiaceae & Perennial & Increaser & 2.50 & 3.01 \\
\hline Valerianella vesicaria & Valerianaceae & Annual & Invasive & 0.50 & 0.60 \\
\hline Total & & & & 83.00 & 100.00 \\
\hline \multicolumn{6}{|c|}{$2-5 \%$} \\
\hline Avena sterilis & Poaceae & Annual & Invasive & 3.75 & 5.30 \\
\hline Bromus tectorum & Poaceae & Annual & Invasive & 1.00 & 1.41 \\
\hline Dactylis glomerata & Poaceae & Perennial & Decreaser & 1.00 & 1.41 \\
\hline Hordeum murinum & Poaceae & Annual & Invasive & 9.50 & 13.43 \\
\hline Hordeum spontaneum & Poaceae & Annual & Invasive & 5.00 & 7.07 \\
\hline Lolium perenne & Poaceae & Perennial & Decreaser & 2.00 & 2.83 \\
\hline Poa bulbosa & Poaceae & Perennial & Increaser & 3.00 & 4.24 \\
\hline Astragalus hamosus & Fabaceae & Annual & Invasive & 9.50 & 13.43 \\
\hline Medicago rigidula & Fabaceae & Annual & Invasive & 2.25 & 3.18 \\
\hline Trifolium campestre & Fabaceae & Annual & Invasive & 3.75 & 5.30 \\
\hline Trifolium subterraneum & Fabaceae & Annual & Invasive & 2.50 & 3.53 \\
\hline Trigonella monantha & Fabaceae & Annual & Invasive & 2.00 & 2.83 \\
\hline Aristolochia bodamae & Aristolochiaceae & Perennial & Invasive & 2.00 & 2.83 \\
\hline Capsella bursa-pastoris & Brassicaceae & Annual & Invasive & 1.75 & 2.47 \\
\hline Cardaria draba & Brassicaceae & Perennial & Invasive & 1.50 & 2.12 \\
\hline Chardinia orientalis & Asteraceae & Annual & Invasive & 2.50 & 3.53 \\
\hline Taraxacum aleppicum & Asteraceae & Perennial & Invasive & 5.00 & 7.07 \\
\hline Parentucellia latifolia & Scrophulariaceae & Annual & Invasive & 2.25 & 3.18 \\
\hline Scandix stellata & Umbelliferae & Annual & Invasive & 3.75 & 5.30 \\
\hline Torilis leptophylla & Umbelliferae & Perennial & Invasive & 4.50 & 6.36 \\
\hline Teucrium polium & Lamiaceae & Perennial & Increaser & 2.25 & 3.18 \\
\hline Total & & & & 70.75 & 100.00 \\
\hline
\end{tabular}


As a matter of fact, Wester (1981) reported that the perennial Poaceae are more common in rangelands with natural vegetation characteristics, and Gökkuş (1994) reported that annuals are commonly found in re-created areas where natural vegetation is degraded.

According to the responses of the species to grazing, in other words, when the distribution of the species according to their quality degrees was examined, of the species determined in the rangeland section with a slope degree of $0-1 \%, 2$ were decreaser, 2 were increaser, and 19 were invasive; and in the rangeland section with a slope degree of $2-5 \%, 2$ of the species were decreaser, 2 were increaser, and 17 were invasive. In the rangeland section with a slope degree of $0-1 \%$, the ratio of decreaser species in the botanical composition of the examined rangeland was $4.51 \%$, the ratio of increaser species was $5.43 \%$, and the ratio of invasive species was $90.06 \%$; and the ratios of the same species were $4.24 \%, 7.42 \%$, and $88.34 \%$, respectively, in the rangeland section with a slope degree of $2-5 \%$ (Table 1; Fig. 3). The invasive species were observed to be more proportionately in the base parts, which have flat or close to the flat slope, of the examined rangeland than the slightly inclined parts of the rangeland. This situation may be explained by the fact that animals prefer flat areas instead of slightly sloping areas and as a result of overgrazing of these areas, plant species with a low feed value replace plant species with a high feed value constituting the vegetation.

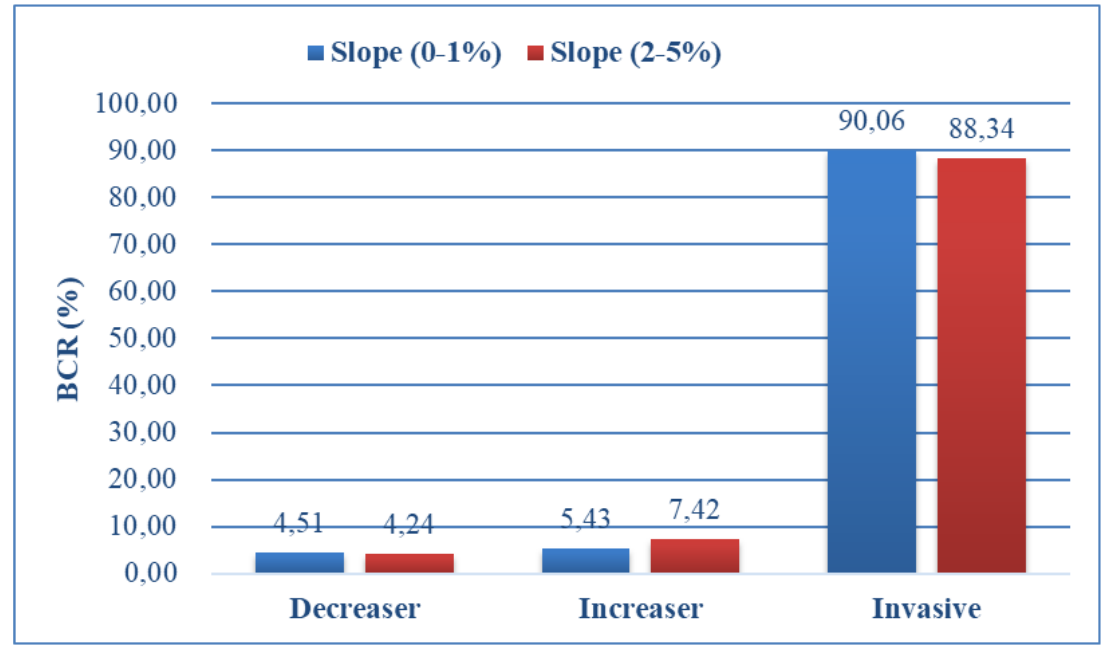

Figure 3. The ratios of species with a different quality degree in the botanical composition in the Gözpinar village rangeland (\%)

Furthermore, in the study, invasive plants had the highest value with $68.63 \%$ in terms of the soil covering ratio, invasive plants were followed by increaser and decreaser plant species with the ratios of $4.87 \%$ and $3.37 \%$, respectively (Table 1 ).

Studies conducted in different regions of Turkey reported that invasive species form the majority of rangeland vegetation (Uzun et al., 2010; Ünal et al., 2013, 2014; Yavuz et al., 2012; Çınar et al., 2014, 2019; Seydoşoğlu et al., 2015a, b; Alay et al., 2016; İspirli et al., 2016; Öten et al., 2016; Seydoşoğlu and Kökten, 2019; Tutar and Kökten, 2019).

Decreaser species, which symbolize dominant and most valuable forage plants of climax vegetation, are species that are grazed by rangeland animals firstly due to the superiority of their palatability (Gençkan, 1985). Lolium perene $(3.31 \%$ and $2.83 \%$ ) and 
Dactylis glomerata $(1.20 \%$ and $1.41 \%)$ were determined as the decreaser species in terms of their ratios in the botanical composition at both slope degrees of the examined rangeland (Table 1).

At both slope degrees, Poa bulbosa (2.42\% and 4.24\%) and Teucrium polium $(3.01 \%$ and $3.18 \%$ ) were found to be increaser species, of which feed values and palatability were lower than those of decreaser species and which are grazed less by rangeland animals (Gençkan, 1985) (Table 1).

In rangeland vegetations, there are foreign plant species, which are not the leading members of climax vegetation, but which are found in the climax rangeland vegetation even at a small ratio, which are not grazed or grazed to a small extent by animals, which are tasteless, which have a low feed value, and which are expressed as invasive species (Gençkan, 1985). In our study, in the rangeland, where vegetation surveys were performed, in both regions having different slope degrees (0-1\% and 2-5\%), according to the ratio in the botanical composition, Hordeum murinum (14.15\% and $13.43 \%)$, Astragalus hamosus (8.44\% and $13.43 \%)$, Hordeum spontaneum (6.63\% and $7.07 \%)$ and Taraxacum aleppicum (6.63\% and $7.07 \%$ ) were determined as prominent invasive species (Table 1).

In the Gözpınar village rangeland where vegetation survey was carried out, the plant covered area ratio (PCR) in the parts of the rangeland having different slope degrees were presented in Table 2. Upon examining Table 2, while the plant covered area value was detected to be $83.00 \%$ in the region of the rangeland having $0-1 \%$ slope degree, it was detected to be $70.75 \%$ in the region having $2-5 \%$ slope degree. In other words, it was found out that the total plant cover decreased with increasing slope degree. The vegetation surveys carried out by İspirli et al. (2016) in 12 different village rangelands which are located in Taşköprü district of Kastamonu province and of which altitudes vary between $612 \mathrm{~m}$ and $1414 \mathrm{~m}$ reported that in parallel with the increase in slope degree, the total plant cover generally decreased. Similarly, Öten et al. (2016) stated that the total plant cover was low in rangeland areas with a high slope degree.

Table 2. PCR values for families according to different slope degrees of the Gözpinar village rangeland compared to $B C R$

\begin{tabular}{c|c|c|c}
\hline Slope degree & Family & PCR (\%) & Total (\%) \\
\hline \multirow{5}{*}{$0-1 \%$} & Poaceae & 29.00 & 83.00 \\
& Fabaceae & 24.00 & 17.00 \\
\cline { 2 - 4 } & Other families & 30.00 & 100.00 \\
\cline { 2 - 4 } & Empty space & 17.00 & \\
\hline \multirow{5}{*}{$2-5 \%$} & Total (BCR) & 100.00 & 70.75 \\
& Poaceae & 25.25 & 29.25 \\
\hline \multirow{5}{*}{ Average } & Fabaceae & 20.00 & 100.00 \\
\cline { 2 - 4 } & Other families & 25.50 & \\
\cline { 2 - 4 } & Empty space & 29.25 & 76.87 \\
\hline & Total (BCR) & 100.00 & 23.13 \\
\cline { 2 - 4 } & Poaceae & 27.13 & 100.00 \\
\hline
\end{tabular}


The average PCR of the Gözpınar village floodplain rangeland of Kurtalan district of Siirt province was detected to be $76.87 \%$ (Table 2). When the vegetation survey studies conducted in different rangeland areas of Turkey were examined, the PCR was determined to vary between $46.2 \%-72.0 \%$ in the floodplain rangelands of Silvan district of Diyarbakır province (Seydoşoğlu et al., 2015a), between 26.60-60.36\% in the steppe rangelands of Eğil district of Diyarbakır province (Seydoşoğlu et al., 2015b), between $75.00 \%-98.25 \%$ in the rangelands of Antalya province (Öten et al., 2016), between $74.00 \%-91.25 \%$ in the rangelands of Beşiri district of Batman province (Seydoşoğlu and Kökten, 2018), between 90.3\%-97.9\% in the rangelands of Tufanbeyli district of Adana province (Çınar et al., 2019), and between 47.50\%-93.00\% in the rangelands of Batman province (Seydoşoğlu and Kökten, 2019). In addition, the average TPC was reported to be $21.75 \%$ in the Zengi rangeland of Isparta province (Babalık and Sarıkaya, 2015), $88.2 \%$ in the natural rangelands of Sinop province (Alay et al., 2016), 83.34\% in the natural rangelands of Taşköprü district of Kastamonu province (İspirli et al., 2016), $71.35 \%$ in the rangelands of Mardin province (Seydoşoğlu et al., 2018), and $85.8 \%$ in the Ormanard1 village rangeland of Bingöl city center (Tutar and Kökten, 2019).

As a result of the study, our findings obtained in terms of the PCR were observed to display similarities and differences with the studies carried out under many ecological conditions. As these differences may be caused by the method differences used in vegetation measurements, it is thought that differences in climate, soil structure, and rangeland management (grazing capacity, animal species, grazing period) applications may also cause this result.

In the Gözpinar village rangeland, in the rangeland region with a slope degree of 0 $1 \%, 29.00 \%$ of the PCR was constituted by the Poaceae, $24.00 \%$ by the Fabaceae, and $30.00 \%$ by plants from other families. In the study, in the region with a slope degree of $2-5 \%$, the PCR ratios of the Poaceae, Fabaceae, and other family plants were detected to be $25.25 \%, 20.00 \%$, and $25.50 \%$, respectively. When the Gözpınar village rangeland was examined in general, $27.13 \%$ of the PCR was observed to be the Poaceae, $22.00 \%$ were observed to be the Fabaceae, and $27.74 \%$ were observed to be the plants from other families (Table 2; Fig. 4).

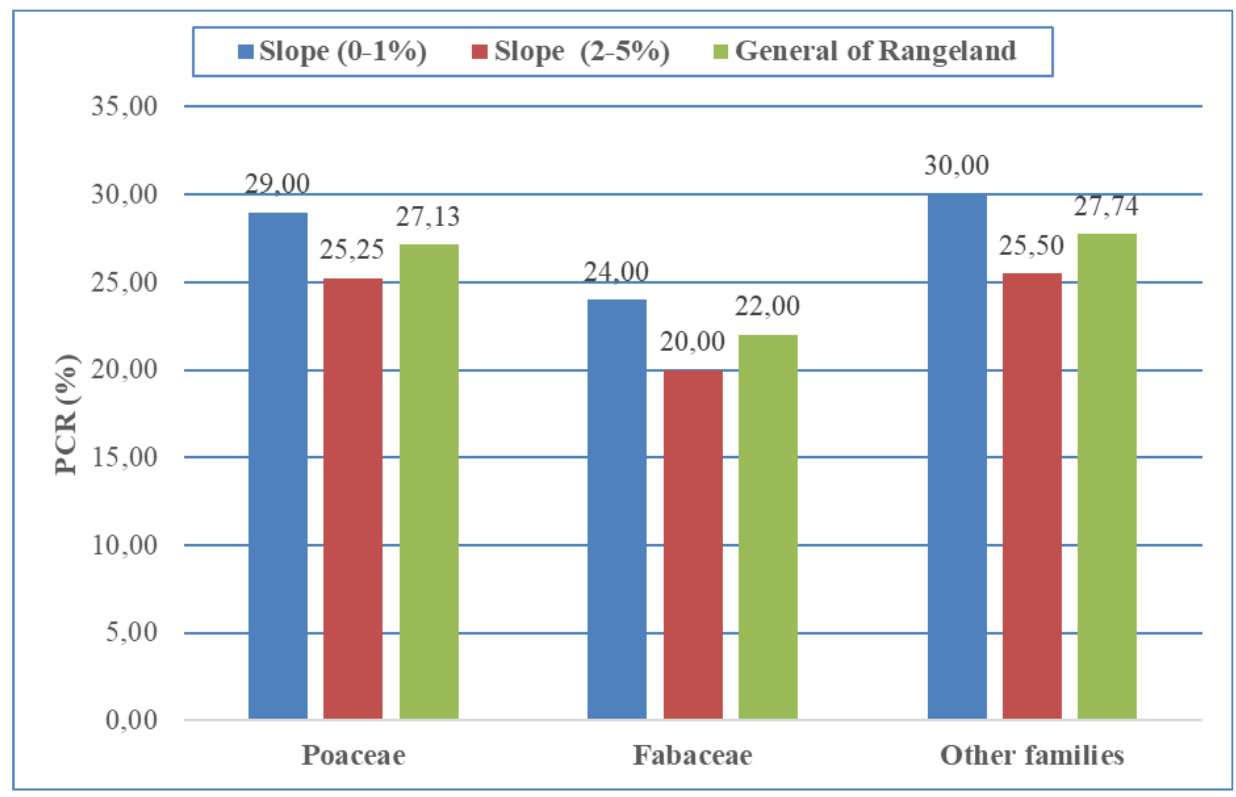

Figure 4. Distribution of the PCR according to families (\%) 
Plant species in the rangeland area were examined by being gathered in three groups as plants from the Poaceae family, Fabaceae family, and other families, and their ratios in the botanical composition were determined according to the PCR (Table 3).

In the Gözpınar village floodplain rangeland, where vegetation surveys were performed, in the rangeland region having 0-1\% slope degree, of the identified species, 7 (34.94\%) were the Poaceae, 6 (28.92\%) were the Fabaceae, and 10 (36.14\%) were species belonging to other families. In the examined rangeland, in the region having a slope degree of $2-5 \%$, of the identified species, 7 (35.69\%) were the Poaceae, 5 $(28.27 \%)$ were the Fabaceae, and $9(36.04 \%)$ were species belonging to other families. In general, the botanical composition of the examined rangeland was composed of the Poaceae with a ratio of $35.32 \%$, the Fabaceae with a ratio of $28.60 \%$, and other families with a ratio of $36.08 \%$ (Table 3; Fig. 5). In this case, it is possible to say that plants belonging to other families constitute the dominant plant group in vegetation. Similar results were also reported by Aydın et al. (2014), Seydoşoğlu et al. (2015b), Alay et al. (2016), İspirli et al. (2016), Öten et al. (2016), Seydoşoğlu and Kökten (2018, 2019), Sürmen and Kara (2018) and Çinar et al. (2019).

Table 3. Ratios of families in the botanical composition ratio

\begin{tabular}{c|c|c|c}
\hline \multirow{2}{*}{ Families } & \multicolumn{3}{|c}{ Botanical composition ratio (\%) } \\
\cline { 2 - 4 } & $\mathbf{0 - 1 \%}$ & $\mathbf{2 - 5 \%}$ & Average \\
\hline Poaceae & 34.94 & 35.69 & 35.32 \\
Fabaceae & 28.92 & 28.27 & 28.60 \\
Other families & 36.14 & 36.04 & 36.08 \\
\hline Total & 100.00 & 100.00 & 100.00 \\
\hline
\end{tabular}

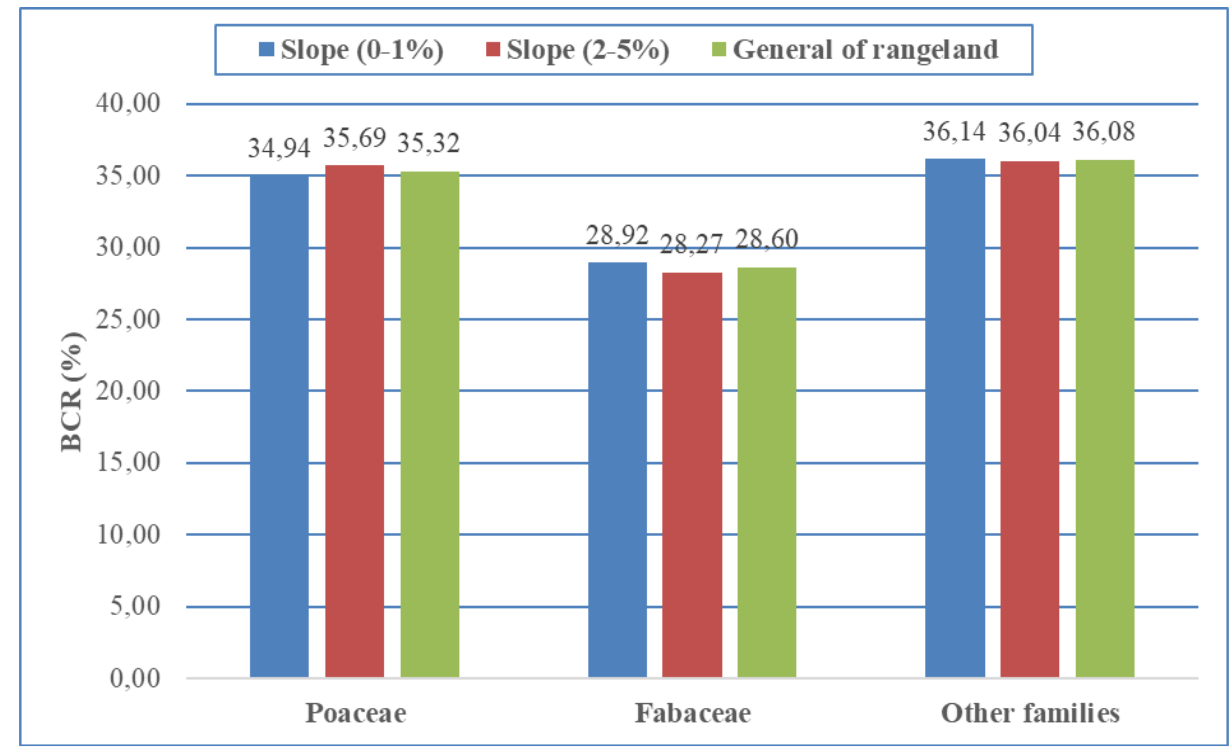

Figure 5. Botanical composition ratios grouped by families

While the most common Fabaceae in the vegetation were Astragalus hamosus (8.44\%, 13.43\%), Trifolium campestre $(6.03 \%, 5.30 \%)$, Medicago rigidula $(5.72 \%$, $3.18 \%)$, and T. subterraneum (4.52\%, 3.53\%); Hordeum murinum (14.15\%, 13.43\%), 
H. spontaneum $(6.63 \%, 7.07 \%)$ and Avena sterilis $(6.03 \%, 5.30 \%)$ were the most commonly observed Poaceae. In vegetation, the most common species belonging to other families were detected to be Scandix stellata $(7.52 \%, 5.30 \%)$, Taraxacum aleppicum $(6.63 \%, 7.07 \%)$, and Torilis leptophylla $(6.03 \%, 6.36 \%)$ (Table 1).

\section{Some physical and chemical properties of rangeland soils}

Some physical and chemical analysis results of the soil samples taken from the regions of the Gözpınar village rangeland with different slope degrees were presented in Table 4. The sand content of the soils belonging to the flat and close to flat (0-1\%) and slightly sloping (2-5\%) rangeland regions was determined to be high. As a result of the classification made according to Anonymous (1951), the texture class was determined to be sandy-loam in the slightly sloping rangeland region and sandy-clayey-loam in the flat rangeland region. According to the general grouping, rangeland soils are loamy soils. Bilgin and Özalp (2016) reported that in the soils belonging to the rangeland vegetation, the texture class did not differ at low elevations (1900, 2000, and $2200 \mathrm{~m}$ ), but the sand content of the soils was high. Özaslan Parlak et al. (2015) reported in the study they conducted in different rangeland regions that sand, silt, and clay contents of rangeland soils significantly differ from each other and that coastal rangeland has sandy loam, lowland shrubland has clayey loam, reseeded rangeland has clayey, protected and overgrazed rangeland has sandy loam structure. Some other studies reported that rangeland soils were loamy or clayey-loamy (Ağın and Kökten, 2013; Çaçan and Kökten, 2014; Taşdemir, 2015).

Table 4. Some physical and chemical properties of soils of the Gözpinar village rangeland according to slope degrees

\begin{tabular}{c|c|c|c}
\hline \multirow{2}{*}{ Soil properties } & \multicolumn{2}{|c|}{ Slope degree } & \multirow{2}{*}{ Average } \\
\cline { 2 - 3 } & $\mathbf{0 - 1 \%}$ & $\mathbf{2 - 5 \%}$ & \\
\hline Sand, \% & 47.32 & 55.36 & 51.34 \\
Clay, \% & 27.44 & 18.98 & 23.21 \\
Silt, \% & 25.24 & 25.66 & 25.45 \\
$\mathrm{pH}$ & 8.25 & 8.25 & 8.25 \\
Total salt, \% & 0.054 & 0.080 & 0.067 \\
Lime $\left(\mathrm{CaCO}_{3}\right), \%$ & 4.1 & 5.4 & 4.8 \\
Organic matter, \% & 1.88 & 1.25 & 1.57 \\
Available phosphorus $(\mathrm{P}), \mathrm{kg} \mathrm{P}_{2} \mathrm{O}_{5} / \mathrm{da}$ & 29.2 & 5.4 & 17.3 \\
Available potassium $(\mathrm{K}), \mathrm{ppm}$ & 6233 & 5116 & 5675 \\
\hline
\end{tabular}

In terms of soil reaction and salinity, no difference was determined between the examined rangeland regions, and the rangeland soil was detected to have slightly alkaline character and be salt-free (Table 4). In the studies conducted in different regions of Turkey, rangeland soils had slightly acid (Şengönül et al., 2009; Bilgin and Özalp, 2016; Çaçan and Kökten, 2014), slightly alkaline (Babalık and Sarıkaya, 2015; Babalık and Ercan, 2018), and neutral character (Ağın and Kökten, 2013; Özaslan Parlak et al., 2015; Taşdemir, 2015), and it was reported that there was no problem in terms of salinity in rangelands. 
While the lime content of the soil was $4.1 \%$ in the regions of the Gözpınar rangeland that were flat or close to flat, this amount was detected to be $5.4 \%$ in the slightly sloping rangeland region (Table 4). According to the classification reported by Ülgen and Yurtsever (1995), the rangeland soils examined were found to be "calcareous" and/or "medium calcareous." The amount of lime varying under the effect of climate and main material was reported to vary at non-calcareous, low calcareous, high calcareous levels in the rangelands of different ecology areas (Bolat, 2007; Sengönül et al., 2009; Ağın and Kökten, 2013; Çaçan and Kökten, 2014; Taşdemir, 2015; Babalık and Sarıkaya, 2015; Özaslan Parlak et al., 2015; Babalık and Ercan, 2018).

The organic matter content of the soil was detected to be $1.88 \%$ in the regions of the Gözpınar village rangeland that were flat or close to flat, and $1.25 \%$ in the slightly sloping rangeland region, and the average organic matter content of the mentioned rangeland was $1.57 \%$ (Table 4). The high organic matter content in the flat region of the rangeland can be explained by the accumulation of nutrients in these areas depending on both soil and water transport towards the base of the rangeland by erosion. However, the organic matter content in both regions was found to be low according to the classification based on the study by Ülgen and Yurtsever (1995). It is thought that the total plant cover and the ratio of the Fabaceae in the botanical composition were effective in the low level of the organic matter content of rangeland soils. In the studies carried out in rangeland areas with different elevation and slope degrees, soil organic matter was generally reported to be at good levels (Babalık and Sarkkaya, 2015; Bilgin and Özalp, 2016; Özaslan Parlak et al., 2015). On the other hand, Birhan (1999) noted that there was no excessive difference between topographic positions in terms of organic matter content and that there was no significant relationship between organic matter content and topographic factors. In the study carried out by Kadioğlu and Canbolat (2014) in order to reveal the change in soil quality index parameters in agricultural and rangeland areas located in different topographic positions, it was determined that from the topographic positions, the structure was thinned and the organic matter content increased from the peak position to the skirt position.

When rangeland soils were examined in terms of the $\mathrm{P}$ and $\mathrm{K}$ content available to plants, the base regions were found to contain higher amounts of $\mathrm{P}$ and $\mathrm{K}$ compared to slightly sloped regions (Table 4). According to the classification reported by Ülgen and Yurtsever (1995), while the available P level of the soil is "very high" in the rangeland regions where the slope degree is flat or close to flat, it is "low" in the slightly sloped regions of the rangeland. According to the classification made by Pizer (1967), the K content of the soil is very high in both rangeland regions. Our findings on the available $\mathrm{P}$ and $\mathrm{K}$ contents of the rangeland soils were found to be compatible with the findings of Ağın and Kökten (2013), Çaçan and Kökten (2014) and Özaslan Parlak et al. (2015).

\section{Conclusion}

There were 23 species in the examined rangeland, and the majority of these species (19 sp.) were found to be invasive. Although the ratio of plant covered area $(76.87 \%)$ was high, the determined ratio of plants belonging to fabaceae, which is important in terms of feeding of animals, was very low. According to these results, it was concluded that in the floodplain rangelands with continental climate, grazing of animals in accordance with the management rules, and improvement of rangeland with fertilization will have a positive effect on the botanical composition of the rangeland. 
Acknowledgements. This study was produced from the first author's master's thesis accepted by the Graduate School of Natural and Applied Science of Siirt University.

\section{REFERENCES}

[1] Ağın, Ö., Kökten, K. (2013): Research on the botanical composition of a range in Karapolat village, Yedisu-Bingöl. - Tr. J. Nature Sci. 2(1): 41-45 (in Turkish).

[2] Alay, F., İspirli, K., Uzun, F., Çınar, S., Aydın, İ., Çankaya, N. (2016): Effects of longterm free grazing on natural rangelands. - Journal of Agricultural Faculty of Gaziosmanpasa University 33(1): 116-124 (in Turkish).

[3] Alkemade, R., Reid, R. S., Van Den Berg, M., De Leeuw, J., Jeuken, M. (2013): Assessing the impacts of livestock production on biodiversity in rangeland ecosystems. Proc. Natl. Acad. Sci. PNAS 110(52): 20900-20905.

[4] Anonymous (1951): Soli Survey Staff, Soil Survey Manuel. - Agricultural Research Administration U. S. Dept. of Agriculture Handbook. No.18, Gount Point Office, Washington, pp. 340-377.

[5] Anonymous (1982): Methods of Soil Analysis. Part II: Chemical and Microbiological Properties. - Agronomy Monograph No: 9. ASA-SSSA, Madison, WI, pp. 323-336.

[6] Anonymous (1986): Methods of Soil Analysis. Part I: Physical and Mineralogical Properties. 2nd Ed. - Agronomy Nomograph No: 9. ASA-SSSA, Madison, WI.

[7] Anonymous (1997): Siirt Province Land Presence. - Publications of General Directorate of Rural Services, Ankara (in Turkish).

[8] Anonymous (2008): Turkey's Meadow and Rangeland Crops. - T. C. Ministry of Agriculture and Rural Affairs, Ankara (in Turkish).

[9] Anonymous (2019a): Basic Statistics, Agriculture. - Turkish Statistical Institute. http://www. tuik.gov.tr/UstMenu.do?metod=temelist (date of access: 15.04.2019; in Turkish).

[10] Anonymous (2019b): Map TR, Map of Gozpinar Village. - https://www.haritatr.com/ gozpinar-koyu-haritasi-m96ba (date of access: 16.06.2019; in Turkish).

[11] Avăg, A., Mermer, A., Yıldız, H., Ünal, E., Urla, Ö., Aydoğdu, M., Dedeoğlu, F., Aydoğmuş, O., Torunlar, H., Tuğaç, M. G., Ünal, S., Mutlu, Z., Özaydın, K. A., Özgöz, M. M., Aksakal, E., Kara, A., Uzun, M., Çakal, S., Yıldırım, T., Aksoyak, S., Tezel, M., Aygün, C., Kara, İ., Erdoğdu, İ., Sever, L., Atalay, A., Yavuz, T., Avcı, M., Çınar, S., İnal, İ., Yücel, C., Cebel, H., Keçeci, M., Başkan, O., Depel, G., Palta, Ç., Çarkacı, A., Karadavut, U., Şimşek, U., Sürmen, M., Odabaşı, G., Gül, D., Koç, A., Erkovan, H. İ., Güllapoğlu, K., Kendir, H., Şahin, N. (2012): National Pasture Use and Management Project Final Report. - TUBİTAK-106G017, Ankara.

[12] Aydın, A., Çaçan, E., Başbağ, M. (2014): Determination of the botanical composition of a pasture in the Derik district of Mardin. - Turkish Journal of Agricultural and Natural Sciences 2(Special Issue): 1625-1630 (in Turkish).

[13] Aydın, İ., Uzun, F. (2005): Nitrogen and phosphorus fertilization of rangelands affects yield, forage quality and the botanical composition. - European Journal of Agronomy 23(1): 8-14.

[14] Aydın, İ., Uzun, F. (2008): Potential decrease of grass tetany risk in rangelands combining $\mathrm{N}$ and $\mathrm{K}$ fertilization with $\mathrm{MgO}$ treatments. - European Journal of Agronomy 29(1): 33-37.

[15] Babalık, A. A., Ercan, A. (2018): Determination of vegetation properties of the Karaören village rangeland in Eskişehir province. - Turkish Journal of Forestry 19(3): 246-251.

[16] Babalık, A. A., Sarikaya, H. (2015): A research on the hay yield and botanical composition of the Zengi Rangeland in Isparta. - Turkish Journal of Forestry 16(2): 96101. 
[17] Bilgin, F., Özalp, M. (2016): Investigating the effects of elevation changes on vegetation structure and soil properties for the pasturelands above forest line. - Artvin Coruh University Journal of Forestry Faculty 17(2): 135-147.

[18] Birhan, H. (1999): Comparison of different topographic positions in terms of yield and some soil properties. - Atatürk University, Institute of Natural and Applied Science, M.Sc. Thesis (in Turkish).

[19] Bolat, İ. (2007): The effect of different land uses on the soil microbial biomass carbon $\left(\mathrm{C}_{\mathrm{mic}}\right)$ and nitrogen $\left(\mathrm{N}_{\mathrm{mic}}\right)$. - Zonguldak Karaelmas University, Institute of Natural and Applied Science, M.Sc. Thesis (in Turkish).

[20] Booker, K., Huntsinger, L., Bartolome, J. W., Sayre, N. F., Stewart, W. (2013): What can ecological science tell us about opportunities for carbon sequestration on arid rangelands in the United States? - Glob. Environ. Chang. 23: 240-251.

[21] Çaçan, E., Kökten, K. (2014): Research on the yield herbage and grazing capacity of a range in Çiçekyayla village, central district Bingöl. - Turkish Journal of Agricultural and Natural Sciences 2: 1727-1733 (in Turkish).

[22] Çaçan, E., Yüksel, A. (2016): Influence of meadows and pastures on regional development. - UNIDAP International Regional Development Conference, Mus, Turkey, pp. 521-531 (in Turkish).

[23] Çınar, S., Hatipoğlu, R., Avcı, M., İnal, İ., Yücel, C., Avağ, A. (2014): A research on the vegetation structures of the pastures in district Kirikhan, Hatay. - Journal of Agricultural Faculty of Gaziosmanpasa University 31(2): 52-60 (in Turkish).

[24] Çınar, S., Hatipoğlu, R., Avcı, M., Yücel, C., İnal, İ. (2019): A research on the vegetation structures of the rangelands of district Tufanbeyli, Adana. - KSU J. Agric Nat 22(1): 143152 (in Turkish).

[25] Davis, P. H. (1969): Flora of Turkey and the Eastaege an Islands. Vols. 1-3. - University of Edinburgh Press, Edinburgh.

[26] Demiri, M. (1983): Flora Ekskursioniste e Shqiperise. - Shtepia Botuese e Librit Shkollor, Tirana.

[27] Demiroğlu Topçu, G., Özkan, Ş. S. (2017): General view to meadow-rangelands and forage crops cultivation of Aegean region and Turkey. - COMU J. Agric. Fac. 5(1): 2128 (in Turkish).

[28] Derner, J. D., Boutton, T. W., Briske, D. D. (2006): Grazing and ecosystem carbon storage in the North American Great Plains. - Plant and Soil 280: 77-90.

[29] Edgecombe, W. (1964): Weeds of Lebanon. - Publication No: 24. Faculty of Agriculture Sciences, American University of Beirut, Lebanon.

[30] Garms, H., Eigener, W., Melderis, A., Pope, T., Durrell, G. (1968): The Natural History of Europe. - Paol Hamilyn Limited, London.

[31] Gençkan, M. S. (1985): Breeding and Management of Meadow-Rangeland Culture. Publication ID: 483. Ege University, Faculty of Agriculture, Publisher of Ege University, Bornova-İzmir (in Turkish).

[32] Gökkuş, A. (1994): Secondary Succession in Abandoned Areas. - Atatürk University Publication ID: 787, Publication Number of Agricultural Faculty: 321, Research Series ID: 197, Erzurum (in Turkish).

[33] Gökkuş, A., Koç, A., Çomaklı, B. (2000): Meadow Pasture Application Guide. Extended 3rd Ed. - Atatürk University Faculty of Agriculture Publications No: 142 (in Turkish).

[34] Gür, M., Altın, M. (2015): Some features of floristic composition of different using history of natural pastures in Thrace Region. - Anadolu Journal of Agricultural Sciences 30: 60-67 (in Turkish).

[35] Huxley, A., Taylor, W. (1977): Flowers of Greece and the Aegean. - Chatto and Windus, London.

[36] İspirli, K., Alay, F., Uzun, F., Çankaya, N. (2016): Impacts of livestock grazing and topography on vegetation cover and structure in natural rangelands. - Turk J Agric Res 3(1): 14-22 (in Turkish). 
[37] Jackson, M. L. (1958): Soil Chemical Analysis. - Prentice-Hall, Inc. Englewood Cliffs, NJ.

[38] Kadığlu, B., Canbolat, M. Y. (2014): Change of soil quality index parameters depending on topographic positions in different agricultural and grazing lands. - Alınteri, 26(B): 1-8 (in Turkish).

[39] Koç, A., Çakal, Ş. (2004): Comparison of some range land canopy coverage methods. Int. Soil Cong. on Natural Resource Manage. For Sust. Develp. June 7-10, ErzurumTurkey, pp. 41-45.

[40] Öten, M., Kiremitci, S., Erdurmuş, C., Soysal, M., Kabaş, Ö., Avc1, M. (2016): Determination of botanical composition of some pastures in Antalya province. - Journal of Atatürk University, Faculty of Agriculture 47(1): 23-30 (in Turkish).

[41] Özaslan Parlak, A., Parlak, M., Gökkuş, A., Demiray, H. C. (2015): Forage yield and quality, botanical composition and some soil characteristics of Mediterranean (Çanakkale) rangelands. - COMU J. Agric. Fac. 3(1): 99-108 (in Turkish).

[42] Öztan, Y., Okatan, A. (1985): Meadow Rangeland, Legume and Grasses Forage Plants Introductory Guide. - Black Sea Technical University Faculty of Forestry, General Publication ID: 95, Faculty Publication ID: 8, Trabzon (in Turkish).

[43] Özyazıc1, M. A., Dengiz, O., İmamoğlu, A. (2014): Determination of some land and soil characteristics of Siirt province with geographic information system analysis. - Turk J Agric Res 1(2): 128-137 (in Turkish).

[44] Pizer, N. H. (1967): Some advisory aspect. Soil potassium and magnesium. - Tech. Bull. 14: 184.

[45] Polat, T., Budak, S., Akkaya, G. (2018): A research on the hay yield, quality and botanical composition of natural grassland of Adiyaman Kuyulu village. - Harran Journal of Agricultural and Food Science 22(3): 348-354 (in Turkish).

[46] Polunin, O., Huxley, A. (1974): Flowers of the Mediterranean. - Chatto and Windus, London.

[47] Sala, O. E., Yahdjian, L., Havstad, K., Aguiar, M. R. (2017): Rangeland Ecosystem Services: Nature's Supply and Humans' Demand. - In: Briske, D. D. (ed.) Rangeland Systems: Processes, Management and Challenges. Series on Environmental Management. Springer, Switzerland, pp. 467-489.

[48] Seydoşoğlu, S., Kökten, K. (2018): Some characters of rangeland vegetation in Batman province of Beşiri district. - Journal of Agriculture Faculty of Ege University 55(4): 491 497 (in Turkish).

[49] Seydoşoğlu, S., Kökten, K. (2019): Some characters of rangeland vegetation in Batman province. - Harran Journal of Agricultural and Food Science 23(1): 60-68 (in Turkish).

[50] Seydoşoğlu, S., Saruhan, V., Mermer, A. (2015a): Research on the vegetation structure of the pastures in Silvan district, Diyarbakır. - Turk J Agric Res 2(1): 1-7 (in Turkish).

[51] Seydoşoğlu, S., Saruhan, V., Mermer, A. (2015b): Determination of the botanical composition of the arid pasture in district Eğil, Diyarbakır. - Turk J Agric Res 2(2): 7682 (in Turkish).

[52] Seydoşoğlu, S., Kökten, K., Sevilmiş, U. (2018): Basic vegetation characteristics of village pastures connected to Mardin province and its provinces. - Turkish Journal of Agricultural and Natural Sciences 5(4): 406-413.

[53] Seydoşoğlu, S., Çaçan, E., Sevilmiş, U. (2019): Determination of botanical composition, yield and pasture quality ratings of infertile pastures in Kozluk district of Batman province of Turkey. - Fresenius Environmental Bulletin 28(4A/2019): 3388-3394.

[54] Sürmen, M., Kara, E. (2018): Yield and quality characteristics of rangelands which have different slopes in Aydın ecological conditions. - Derim 35(1): 67-72 (in Turkish).

[55] Şengönül, K., Kara, Ö., Palta, Ş., Şensoy, H. (2009): Determination of some quantitative properties of range vegetation and ecological conditions in Bartın Uluyayla. - Journal of Bartin Faculty of Forestry 11(16): 81-94 (in Turkish). 
[56] Taşdemir, V. (2015): Research on the hay yield and botanical composition of a range in Bahcecik village, Karakocan-Elazıg. - Bingöl University, Institute of Natural and Applied Science, M.Sc. Thesis (in Turkish).

[57] Terzioğlu, Ö., Yalvaç, N. (2004): A research on determination of grazing starting time hay yield and botanical composition of natural rangelands in Van region. - J. Agric. Sci. 14(1): 23-26 (in Turkish).

[58] Tutar, H., Kökten, K. (2019): Determination of botanical composition of Ormanard1 village rangeland in Bingöl province center. - Turkish Journal of Agricultural and Natural Sciences 6(1): 16-23 (in Turkish).

[59] Ülgen, N., Yurtsever, N. (1995): Turkey Fertilizer and Fertilization Guide. 4. Press. Publications of Soil and Fertilizer Research Institute, General Publication No: 209, Technical Publication No: T.66. General Directorate of Rural Services, Ankara (in Turkish).

[60] Ünal, S., Mutlu, Z., Urla, Ö., Y1ldız, H., Şahin, B. (2013): Evaluation and determination of rangeland vegetation in Kayseri province. - Journal of Central Research Institute for Field Crops 22(2): 86-95.

[61] Ünal, S., Mutlu, Z., Urla, Ö., Yıldız, H., Aydoğdu, M., Şahin, B., Aslan, S. (2014): Improvement possibilities and effects of vegetation subjected to long-term heavy grazing in the stepe rangelands of Sivas. - Journal of Central Research Institute for Field Crops 23(1): 22-30.

[62] Uzun, F., Garipoğlu, A. V., Algan, D. (2010): Plant characteristics and control of yellow starhistle (Centaurea solstitialis L.) appeared at our rangelands. - Anadolu J. Agric. Sci. 25(3): 213-222 (in Turkish).

[63] Wester, L. (1981): Composition of native grasslands in the San Joaquin Valley, California. - Madroño 28: 231-241.

[64] Weymer, H. (1981): Lernt Pflanzen Kennen. - Ferdinand Enke Verlag, Stuttgart.

[65] Yavuz, T., Sürmen, M., Töngel, M. Ö., Avağ, A., Özaydın, A. K., Yıldız, H. (2011): Vegetation characteristics of pastures in Samsun province. - 9. Field Crops Congress of Turkey, 12-15 September, Bursa, pp. 1773-1778 (in Turkish).

[66] Yavuz, T., Sürmen, M., Töngel, M. Ö., Avağ, A., Özaydın, K., Yıldız, H. (2012): Some characters of pasture vegetation in Amasya province. - TABAD 5(1): 181-185 (in Turkish). 